\title{
Nitrogenase derepresssion, its regulation and metabolic changes associated with diazotrophy in the non-heterocystous cyanobacterium Plectonema boryanum PCC 73110
}

\author{
A. N. RAI, ${ }^{1 *}$ M. BorthaKuR ${ }^{1}$ and B. Bergman ${ }^{2}$ \\ ${ }^{1}$ Department of Biochemistry, North-Eastern Hill University, Shillong 793014, India \\ ${ }^{2}$ Department of Botany, Stockholm University, S-10691 Stockholm, Sweden
}

(Received 24 July 1991; revised 30 September 1991; accepted 15 November 1991)

\begin{abstract}
The regulation of nitrogenase derepression, plus the catalytic activity and protein concentration of glutamine synthetase (GS), nitrate reductase (NR), ribulose-1,5-bisphosphate carboxylase/oxygenase (Rubisco) and phycoerythrin (PE) were studied in the filamentous non-heterocystous cyanobacterium Plectonema boryanum PCC 73110. Both nitrogen limitation and microaerobic incubation were essential for the derepression of nitrogenase. Oxygen caused irreversible inactivation of nitrogenase, as well as repression of its synthesis. A temporal separation of $\mathrm{N}_{2}$ fixation and net photosynthetic $\mathrm{O}_{2}$ evolution was observed under a $\mathrm{N}_{2} / \mathrm{CO}_{2}(95: 5$, v/v) atmosphere. Repeated peaks of nitrogenase and growth were observed. Immunogold localization showed that in $\mathbf{N}_{2}$-fixing cultures, all cells, including those undergoing division, contained nitrogenase, and that the nitrogenase antigen was uniformly distributed throughout the cells without any preferential association with cellular structures. Rubisco was mainly located in carboxysomes of both $\mathrm{N}_{2}$-fixing and $\mathrm{NO}_{3}^{-}$-grown cells. Both $\mathrm{N}_{2}$-fixing and $\mathrm{NO}_{3}^{-}$grown cells showed similar levels of PE, which was associated with the thylakoid membranes. GS antigen was distributed throughout the cells and the relative amounts of this enzyme, as well as its activity, were $20 \%$ higher in $\mathrm{N}_{2}$-fixing than in $\mathrm{NO}_{3}^{-}$-grown cultures. $\mathrm{NO}_{3}^{-}$uptake and $\mathrm{NR}$ systems were found to be $\mathrm{NO}_{3}^{-}$-inducible, with very low activities in $\mathrm{N}_{2}$-fixing cultures. The latter may be important in avoiding competition for Mo between nitrogenase and NR.
\end{abstract}

\section{Introduction}

Cyanobacteria are $\mathrm{O}_{2}$-evolving photosynthetic prokaryotes, many of which are also capable of autotrophic growth using $\mathbf{N}_{2}$ as the sole nitrogen source (Stewart, 1980; Gallon, 1989). Cellular integration of $\mathbf{N}_{2}$ fixation in cyanobacteria requires strategies for protection of nitrogenase from atmospheric and photosynthetically produced $\mathrm{O}_{2}$, provision of ATP and reductant, and efficient assimilation of $\mathrm{N}_{2}$-derived ammonium. In some cyanobacteria this is achieved by development of specialized cells called heterocysts, resulting in spatial separation of photosynthesis (located in vegetative cells)

\footnotetext{
* Author for correspondence. Tel. (0364) 25136.

Abbreviations: ATCC, American Type Culture Collection; GOGAT, glutamate synthase; GS, glutamine synthetase; NR, nitrate reductase; PCC, Pasteur Culture Collection; PE, phycoerythrin; Rubisco, ribulose-1,5-bisphosphate carboxylase/oxygenase; TEM, transmission electron microscopy; UTEX, culture collection of algae at University of Texas (formerly Indiana University Culture Collection).
}

and $\mathrm{N}_{2}$ fixation (located in heterocysts); fixed carbon moves from vegetative cells to heterocysts and fixed nitrogen from heterocysts to vegetative cells (Stewart, 1980; Wolk, 1982; Bergman et al., 1986). Several other metabolic changes conducive to nitrogenase functioning occur during heterocyst development, including: (1) loss of photosynthetic $\mathrm{O}_{2}$ evolution, phycobiliproteins and ribulose-1,5-bisphosphate carboxylase/oxygenase (Rubisco); (2) increases in respiratory activity and in the activity of enzymes of the oxidative pentose phosphate pathway; (3) loss of nitrate uptake and nitrate reductase (NR) systems; (4) increased levels of glutamine synthetase (GS) necessary for assimilation of $\mathrm{N}_{2}$-derived ammonia (Wolk, 1982; Kumar et al., 1985; Rai \& Bergman, 1986; Renström-Kellner et al., 1990).

The strategies for $\mathrm{O}_{2}$ protection during aerobic $\mathrm{N}_{2-}$ fixation by non-heterocystous cyanobacteria have been studied in detail, with the conclusion of a temporal separation of $\mathbf{N}_{2}$-fixation and photosynthesis (see Gallon, 1989). However, very few studies have been conducted on non-heterocystous cyanobacteria which fix 
$\mathrm{N}_{2}$ only under microaerobic or anaerobic conditions. The reasons for the lack of aerobic $\mathbf{N}_{2}$-fixation in such cyanobacteria are not fully understood. Under microaerobic to anaerobic conditions, a temporal separation of net $\mathrm{O}_{2}$ evolution and nitrogenase activity has been observed in Plectonema boryanum (Weare \& Benemann, 1974) and Phormidium faveolarum (Weisshaar \& Böger, 1983). However, repeated peaks of alternating nitrogenase activity and oxygen evolution or growth have not been demonstrated. On the other hand, there are conflicting reports of $\mathrm{N}_{2}$ fixation and concomitant growth in Plectonema boryanum (Rogerson, 1980; Pearson \& Howsley, 1980; Giani \& Krumbein, 1986). Furthermore, virtually no information is available regarding levels of phycoerythrin (PE), GS, nitrate uptake, NR and Rubisco under diazotrophic growth conditions in these cyanobacteria.

Plectonema boryanum PCC 73110 is a filamentous nonheterocystous cyanobacterium which fixes $\mathrm{N}_{2}$ under microaerobic to anaerobic conditions (Stewart \& Lex, 1970). In the present investigation, we used this strain to study the derepression, subcellular localization and regulation of nitrogenase, and changes in GS, Rubisco, PE, nitrate uptake and NR when nitrate-grown cultures adapted to diazotrophic growth.

\section{Methods}

Organism and growth conditions. Plectonema boryanum PCC 73110 (ATCC 29407 and UTEX 594) and Gloeothece PCC 6909 (ATCC 27152 and UTEX 795) were grown in batch cultures using BG-11 medium (Rippka et al., 1979) at $25^{\circ} \mathrm{C}$ and a photon fluence rate of $20 \mu \mathrm{mol} \mathrm{m} \mathrm{m}^{-2} \mathrm{~s}^{-1}$. Oscillatoria limosa (Stal \& Bergman, 1990) was grown on artificial sea water medium $\mathrm{ASN}_{3}$ (Rippka et al., 1979) at $20^{\circ} \mathrm{C}$ and a photon fluence rate of $20 \mu \mathrm{mol} \mathrm{m} \mathrm{m}^{-2} \mathrm{~s}^{-1}$. $\mathrm{N}_{2}$-fixing cultures of Gloeothece and $O$. limosa were obtained by transferring the cultures to nitrogen-free media (' $\mathrm{N}_{2}$-medium'; $\mathrm{BG}-11_{0}$ and $\mathrm{NO}_{3}^{-}$-free $\mathrm{ASN}_{3}$, respectively). Derepression of nitrogenase in $P$. boryanum was achieved as described below.

Nitrogenase derepression. Aerated batch cultures of $\boldsymbol{P}$. boryanum grown on BG-11 medium were harvested by centrifugation during the exponential phase. The cells were washed and resuspended in BG-1 $1_{0}$ medium to a cell density of $200 \mu \mathrm{g} \mathrm{ml}^{-1}$ ( $3 \mu \mathrm{g}$ chlorophyll $a \mathrm{ml}^{-1}$ ). These cultures were subdivided into $20 \mathrm{ml}$ batches and transferred to $100 \mathrm{ml}$ capacity serum-stoppered Erlenmeyer flasks. These were sparged with the desired gas mixture at specified times and maintained at $25^{\circ} \mathrm{C}$ and a photon fluence rate of $10 \mu \mathrm{mol} \mathrm{m}^{-2} \mathrm{~s}^{-1}$. These flasks were directly used for acetylene reduction assay, each assay lasting $30 \mathrm{~min}$; the cultures were not transferred to another vessel, in order to avoid air contamination.

Enzyme assays. Nitrogenase activity (EC 1.18.6.1) was estimated in vivo by gas chromatography using the acetylene reduction assay (Stewart et al., 1967). GS biosynthetic activities (EC 6.3.1.2) were measured in cell extracts as described by Sampaio et al. (1979). Ferredoxin-dependent NR activity was measured in cells made permeable with toluene, using methyl viologen as electron donor, by

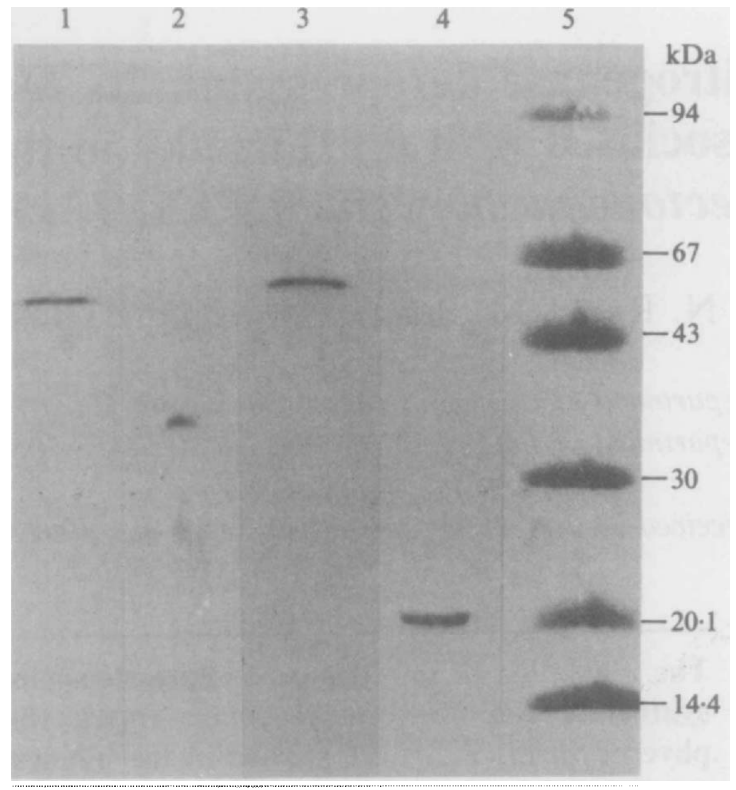

Fig. 1. SDS-PAGE and immunoblotting of cell extracts from $\mathrm{N}_{2}$ fixing $P$. boryanum. $\mathrm{NO}_{3}^{-}$-grown cells were transferred to $\mathrm{N}_{2}$-medium and nitrogenase induced as described in Fig. 2(b). Immunoblots of GS (lane 1), nitrogenase Fe-protein (lane 2), Rubisco (lane 3) and PE (lane 4) are shown. Lane 5, molecular mass markers.

following the formation of $\mathrm{NO}_{2}^{-}$from $\mathrm{NO}_{3}^{-}$as described by Manzano et al. (1976). $\mathrm{NO}_{3}^{-}$was estimated colorimetrically as described by Snell \& Snell (1949).

$\mathrm{NO}_{3}^{-}$uptake. This was measured by estimating the rate of disappearance of $\mathrm{NO}_{3}^{-}$from the medium (final concentration $100 \mu \mathrm{M}$ ). $\mathrm{NO}_{3}^{-}$was estimated by the difference in absorbance between 202 and $250 \mathrm{~nm}$ as described by Calero et al. (1980).

Protein and chlorophyll $a$. Protein concentration was measured according to Bradford (1976) and chlorophyll $a$ according to MacKinney (1941).

$\mathrm{O}_{2}$ exchange. $\mathrm{O}_{2}$ evolution and consumption were measured using a polarographic Clark-type oxygen electrode installed in a $3 \mathrm{ml}$ Plexiglass container with magnetic stirring. The measurements were done at $25^{\circ} \mathrm{C}$ and at a photon fluence rate of $10 \mu \mathrm{mol} \mathrm{m}^{-2} \mathrm{~s}^{-1}$.

Antibodies. Rabbit anti-Rhodospirillum rubrum nitrogenase $\mathrm{Fe}-$ protein, anti-Anabaena PCC 7120 GS, anti-Phormidium persicinum PE and anti-Sinapis alba Rubisco were gifts from Dr S. Nordlund (University of Stockholm, Sweden), Professor R. Haselkorn (University of Chicago, USA), Dr D. Guard-Friar (New York State Department of Health, USA) and Dr R. Oelmuller (University of Freiburg, Germany), respectively. The specificity of these antibodies was tested against crude extracts of $\mathrm{N}_{2}$-fixing $P$. boryanum cells by Western blotting (Fig. 1). All antibodies were found to be monospecific, recognizing a single polypeptide of known subunit molecular mass relating to their respective antigens (nitrogenase $36 \mathrm{kDa}$; GS $53 \mathrm{kDa}$; Rubisco $56 \mathrm{kDa}$; PE $20 \mathrm{kDa}$ ) (see also Bergman \& Rai, 1989). Secondary antibodies (goat anti-rabbit IgG conjugated to colloidal gold size 5 or $10 \mathrm{~nm}$, and conjugated to horseradish peroxidase) were obtained from Amersham and Bio-Rad, respectively.

Western blotting. P. boryanum cells were harvested by centrifugation $(3000 \mathrm{~g}, 5 \mathrm{~min})$ and the pellet resuspended in sample buffer $(1: 1, \mathrm{v} / \mathrm{v})$ consisting of $10 \mathrm{mM}-\mathrm{Tris} / \mathrm{HCl}$ (pH 8), $1 \mathrm{mM}-\mathrm{EDTA}, 2.5 \% \mathrm{SDS}, 5 \%$ 
$\beta$-mercaptoethanol and $0.01 \%$ bromophenol blue. These samples were boiled for $5 \mathrm{~min}$ and centrifuged at $15000 \mathrm{~g}$ for $5 \mathrm{~min}$. Samples $(1 \mu \mathrm{l})$ of the supernatant were used for SDS-PAGE and subsequent immunoblotting as described by Braun-Howland et al. (1988), using antibodies against nitrogenase Fe-protein, GS, PE and Rubisco at a dilution of $1: 500(\mathrm{v} / \mathrm{v})$.

Immunogold labelling. Preparation of samples for transmission electron microscopy (TEM) and the protocols for immunolabelling were essentially the same as described before (Bergman et al., 1985) except that the secondary antibody (goat anti-rabbit $\mathrm{IgG}$ ) was conjugated to size 5 or $10 \mathrm{~nm}$ colloidal gold and that different primary antibodies were used as required (see figure legends). Five grids containing ultrathin sections of $\mathrm{NO}_{3}^{-}$-grown and $\mathrm{N}_{2}$-fixing $P$. boryanum samples were immunolabelled. For quantification, 10-15 photographs were taken, of which one set of representative photographs is presented. In control experiments, the primary antibody was omitted.

TEM and quantification of the immunolabel. TEM was performed using a Zeiss EM 10 transmission electron microscope operated at $60 \mathrm{kV}$. Relative levels of various antigens were estimated by counting gold particles in various cell types using TEM photographic prints. These were then converted to number of gold particles per $\mu \mathrm{m}^{2}$ cell area taking into account the magnification of the prints used and the area counted. In total, $100 \mu \mathrm{m}^{2}$ cell area was counted in each case and the values presented are means ( $\pm \mathrm{SE}$ ) from $10-15$ counts. A similar exercise was done to calculate background labelling by counting gold particles per unit area outside the cells. Background labelling was also calculated in control experiments where primary antibody was omitted during immunolabelling.

Chemicals and gases. All the supplies for electron microscopy were obtained from Agar Aids, for electrophoresis from Pharmacia and for immunoblotting from Bio-Rad. All other chemicals were from Sigma. Gases were obtained from AGA Special Gases, Stockholm.

\section{Results}

\section{Derepression of nitrogenase}

No nitrogenase activity or protein could be detected in $\mathrm{NO}_{3}^{-}-$or $\mathrm{NH}_{4}^{+}$-grown $P$. boryanum cultured either under air or with $\mathrm{N}_{2} / \mathrm{CO}_{2}(95: 5, \mathrm{v} / \mathrm{v})$ sparging (data not shown). Upon transfer to $\mathrm{N}_{2}$-medium and periodic sparging with $\mathrm{N}_{2} / \mathrm{CO}_{2}$, development of acetylenereducing activity started after $30 \mathrm{~h}$ (Fig. $2 a$ ). The activity continued to increase during the next $40 \mathrm{~h}$, after which it steadily declined. The pattern and specific activity were similar to those noted by Stewart \& Lex (1970). However, when the cells were nitrogen starved for $24 \mathrm{~h}$ under aerobic conditions prior to the periodic $\mathrm{N}_{2} / \mathrm{CO}_{2}$ sparging, acetylene-reducing activity developed much faster (within $2 \mathrm{~h}$ ) and reached a peak by $6-7 \mathrm{~h}$ (Fig. $2 b$ ), with maximal specific activity similar to that in Fig. 2(a). To see if the faster development of nitrogenase activity was due to the activation of pre-existing nitrogenase protein developed during the $24 \mathrm{~h}$ nitrogen starvation, development of acetylene-reducing activity was followed in cells where chloramphenicol or rifampicin was added at the end of nitrogen starvation and just before the start of
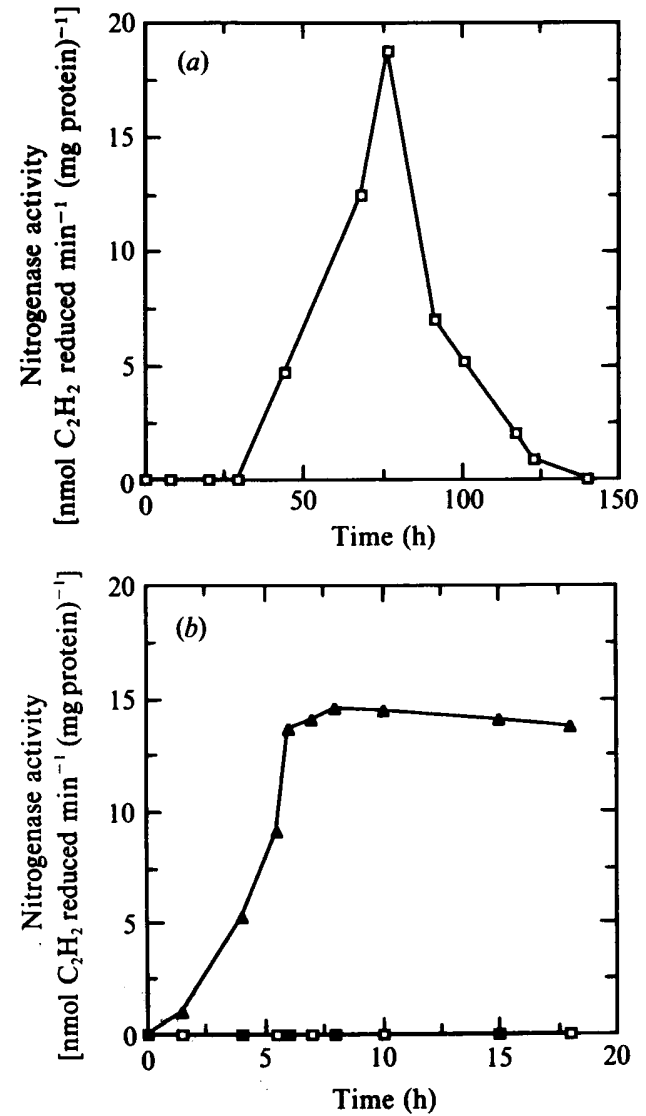

Fig. 2. Nitrogenase induction in $P$. boryanum. (a) $\mathrm{NO}_{3}^{-}$-grown cells were transferred to $\mathrm{N}_{2}$-medium as detailed in Methods and maintained at $25^{\circ} \mathrm{C}$ with a photon fluence rate of $10 \mu \mathrm{mol} \mathrm{m}^{-2} \mathrm{~s}^{-1}$. Starting at zero time and at $6 \mathrm{~h}$ intervals they were sparged for $15 \mathrm{~min}$ with $\mathrm{N}_{2} / \mathrm{CO}_{2}$ $(95: 5, \mathrm{v} / \mathrm{v})$ at a rate of $1000 \mathrm{ml} \mathrm{h}^{-1}$. Nitrogenase activity was measured in 30 min assays under a $\mathrm{N}_{2} / \mathrm{CO}_{2}$ gas phase and under the light and temperature conditions mentioned above. In this and other figures the nitrogenase activity quoted is the mean of that during the $\mathbf{3 0}$ min before the points shown. (b) Same as (a) except that prior to the start of $\mathrm{N}_{2} / \mathrm{CO}_{2}$ sparging (zero time) the cultures were nitrogen starved for $24 \mathrm{~h}$ by incubating them in $\mathrm{N}_{2}$-medium with continuous air sparging $\left(2000 \mathrm{ml} \mathrm{h}^{-1}\right)$. Symbols in $(b): \Delta$, control; $\square$, plus chloramphenicol $\left(100 \mu \mathrm{g} \mathrm{ml}^{-1}\right) ; \square$, plus rifampicin $\left(100 \mu \mathrm{g} \mathrm{ml}^{-1}\right)$. Chloramphenicol and rifampicin were added at the start of $\mathrm{N}_{2} / \mathrm{CO}_{2}$ sparging (i.e. after the aerobic nitrogen-starvation period). This and other experiments (Figs $3 a, 4,5,6)$ were all done in duplicate. The values presented are means of two measurements from each replicate.

$\mathrm{N}_{2} / \mathrm{CO}_{2}$ sparging. As seen in Fig. 2(b), acetylenereducing activity did not appear under such conditions. These results indicate that nitrogenase protein was absent during the aerobic nitrogen starvation period and that the derepression on $\mathrm{N}_{2} / \mathrm{CO}_{2}$ sparging was due to fresh synthesis of nitrogenase. An absence of nitrogenase protein in aerobic cultures was also observed by immunoblotting cell extracts of $\boldsymbol{P}$. boryanum which had been nitrogen starved for $30 \mathrm{~h}$ under aerobic conditions (Fig. 3b, lane 1). These results show that nitrogenase 

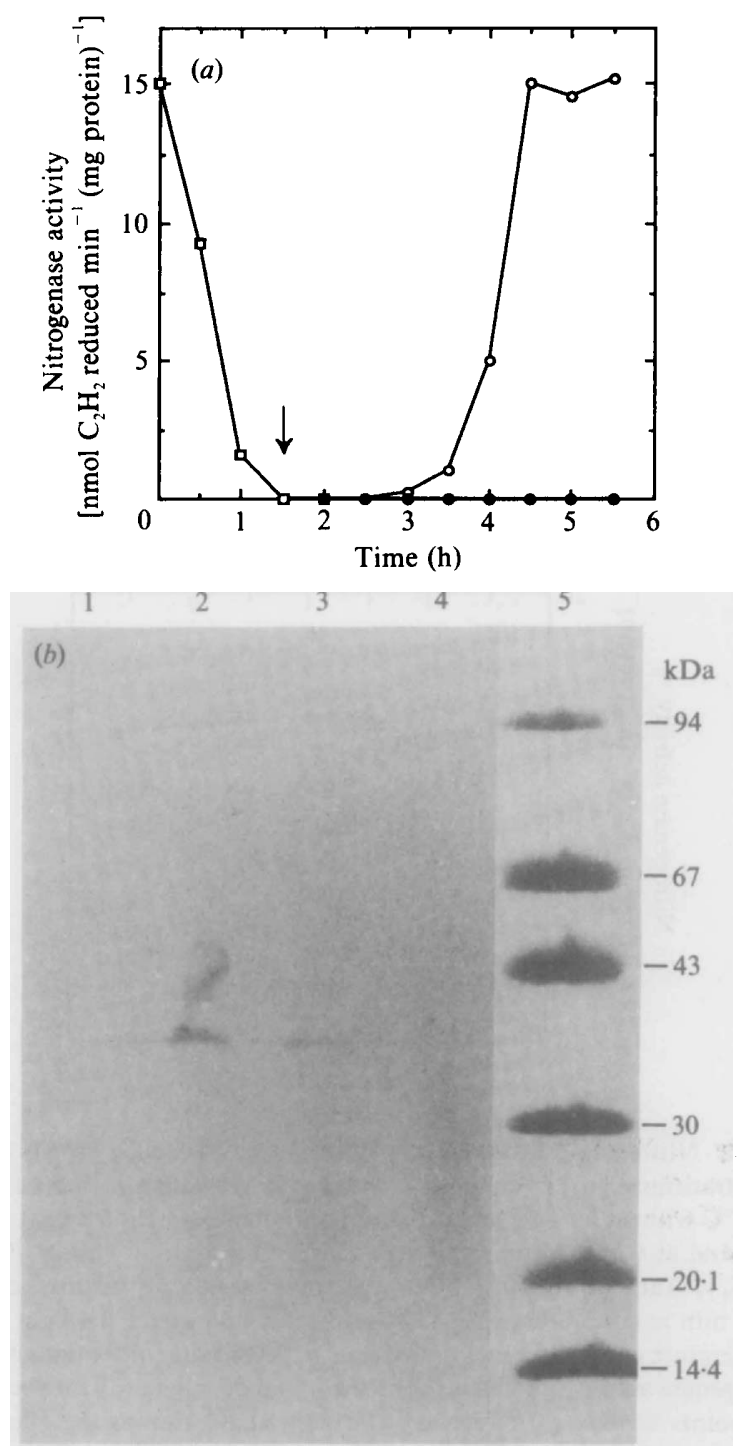

Fig. 3. (a) Loss of nitrogenase activity on exposure to air $(\square)$ and its regain upon transfer to a $\mathrm{N}_{2} / \mathrm{CO}_{2}$ atmosphere $(\mathrm{O}, \bullet)$ in $P$. boryanum. Nitrogenase derepression was achieved as in Fig. 2(b) and after appearance of the nitrogenase peak, the cells were sparged with air for $5 \mathrm{~min}$ at the rate of $2000 \mathrm{ml} \mathrm{h}^{-1}$. Nitrogenase activity was measured at $30 \mathrm{~min}$ intervals under aerobic conditions. At the time indicated by the arrow, the gas phase was changed to $\mathrm{N}_{2} / \mathrm{CO}_{2}$ and nitrogenase activity measured at $30 \mathrm{~min}$ intervals under $\mathrm{N}_{2} / \mathrm{CO}_{2}$ in the absence $(O)$ and presence (๑) of chloramphenicol or rifampicin (both $100 \mu \mathrm{g} \mathrm{ml}^{-1}$ ). (b) Detection of nitrogenase Fe-protein by immunoblotting in cell extracts of $P$. boryanum. Lane 1, extract from cells maintained in aerobic $\mathbf{N}_{2^{-}}$ medium for $30 \mathrm{~min}$; lane 2, extract from cells with peak nitrogenase activity; lane 3 , extract from cells which were exposed to air for $2 \mathrm{~h}$ after appearance of the nitrogenase peak; lane 4, extract of cells which had been exposed to air for $4 \mathrm{~h}$ after appearance of nitrogenase activity; lane 5, molecular mass markers.

derepression required both low cellular nitrogen and microaerobic to anaerobic conditions, and that the longer time required for nitrogenase derepression in Fig. $2(a)$ was due to the time required for the depletion of
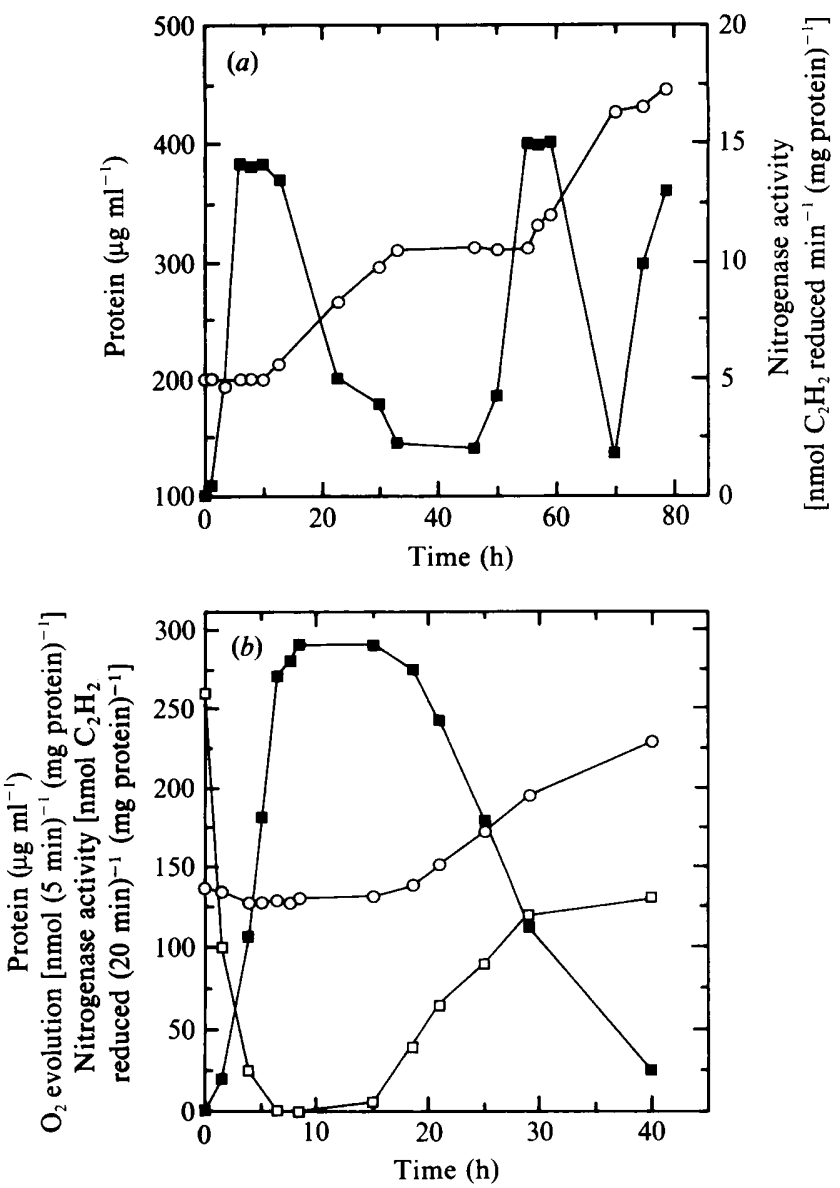

Fig. 4. (a) Nitrogenase activity ( $\boldsymbol{(})$ and protein content $(O)$ of $P$. boryanum. (b) Nitrogenase activity $(\square)$, protein content $(O)$ and net $\mathrm{O}_{2}$ evolution rate ( $\square$ ) during the first phase of $\mathrm{N}_{2}$ fixation in (a). Culture conditions and other details as in Fig. 2(b) control.

intracellular nitrogen reserves under non-optimal growth conditions.

Re-exposure of $\mathrm{N}_{2}$-fixing $P$. boryanum cells to air caused a rapid decline in acetylene-reducing activity, which became undetectable after $90 \mathrm{~min}$ of exposure (Fig. 3a). To see whether the decline in nitrogenase activity was due to inactivation of the enzyme or to protein degradation/modification, immunoblots of cell extracts were done using $P$. boryanum cells exposed to air for increasing periods of time after the appearance of peak nitrogenase activity (Fig. $3 b$ ). After $2 \mathrm{~h}$ of exposure to air, when nitrogenase activity had become undetectable, nitrogenase Fe-protein was still detectable (lane 3), although the cross-reaction was less intense than that in $P$. boryanum cells under $\mathrm{N}_{2} / \mathrm{CO}_{2}$ (lane 2 ). In both cases, only a single polypeptide of $36 \mathrm{kDa}$ was detected corresponding to nitrogenase Fe-protein. These data indicate that loss of nitrogenase activity on exposure to air was due to nitrogenase inactivation followed by degradation. Such inactivation did not involve modification of Fe-protein to a higher molecular mass form as 


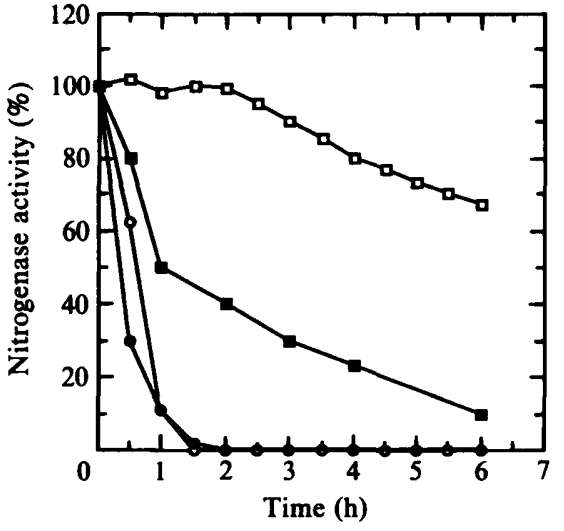

Fig. 5. Effects of air, darkness, $\mathrm{NH}_{4}+$ and $\mathrm{NO}_{3}^{-}$on nitrogenase activity in $P$. boryanum. Nitrogenase activity was derepressed as in Fig. $2(b)$. After the appearance of the nitrogenase peak, the conditions were changed (zero time) and the response of nitrogenase activity was monitored during the next $6 \mathrm{~h}$. $\bullet$, Cultures transferred to darkness; $\square$, $\mathrm{NH}_{4} \mathrm{Cl}$ added to a final concentration of $2 \mathrm{mM} ; \square, \mathrm{KNO}_{3}$ added to a final concentration of $10 \mathrm{mM}$; $O$, cultures transferred to aerobic atmosphere. The $\mathrm{NH}_{4} \mathrm{Cl}$ and $\mathrm{KNO}_{3}$ solutions were sparged with $\mathrm{N}_{2} / \mathrm{CO}_{2}$ for $30 \mathrm{~min}$ before addition. The solutions were also buffered with $10 \mathrm{mM}-\mathrm{HEPES} / \mathrm{NaOH}$ (pH 7.5). One hundred percent activity represents $18 \mathrm{nmol} \mathrm{C}_{2} \mathrm{H}_{4}$ formed $\mathrm{min}^{-1}$ (mg protein) ${ }^{-1}$.

noted in other cyanobacteria (Ernst et al., 1990; Reich \& Böger, 1989; Smith et al., 1987; Stal \& Bergman, 1990). To see if the inactivation of the nitrogenase was reversible, $P$. boryanum cells were transferred back to a $\mathrm{N}_{2} / \mathrm{CO}_{2}$ atmosphere after $90 \mathrm{~min}$ of exposure to air (Fig. $3 a$ ). Acetylene-reducing activity reappeared after $90 \mathrm{~min}$ and reached a peak in $3 \mathrm{~h}$. Such reappearance of nitrogenase activity was sensitive to chloramphenicol and rifampicin. Thus, inactivation of nitrogenase under air was concluded to be irreversible.

Growth, $\mathrm{N}_{2}$ fixation and $\mathrm{O}_{2}$ evolution

When nitrogenase was derepressed as in Fig. 2(b), and the cultures maintained under similar conditions over a prolonged period, repeated peaks of acetylene-reducing activity were observed (Fig. $4 a$ ). An increase in protein content, which was taken as indicative of growth, followed. A detailed analysis of one such peak of nitrogenase activity and growth phase (Fig. $4 b$ ) showed that during the appearance of nitrogenase the rate of net $\mathrm{O}_{2}$ evolution declined rapidly, becoming undetectable by the time nitrogenase activity reached its peak. No growth occurred during this period. Net $\mathrm{O}_{2}$ evolution was detectable again after $7 \mathrm{~h}$. This coincided with growth and with a decline in nitrogenase activity. These data indicate that under the conditions used here, $P$. boryanum can grow photoautotrophically using $\mathrm{N}_{2}$ as nitrogen source, in repeated cycles of $\mathrm{N}_{2}$ fixation and growth, and under such conditions there is a temporal separation of net $\mathrm{O}_{2}$ evolution and nitrogenase activity. During the maximal $\mathrm{N}_{2}$-fixing period, $\mathrm{O}_{2}$ evolution may be balanced by respiratory $\mathrm{O}_{2}$ consumption, resulting in the absence of net $\mathrm{O}_{2}$ exchange.

\section{Effects of $\mathrm{NH}_{4}^{+}$and $\mathrm{NO}_{3}^{-}$and darkness on nitrogenase activity}

After nitrogenase derepression as in Fig. 2(b), the effects of darkness, $\mathrm{NH}_{4}^{+}$and $\mathrm{NO}_{3}^{-}$were studied during the $6 \mathrm{~h}$ stable period when maximal nitrogenase activity was expressed. Transfer of $\mathrm{N}_{2}$-fixing cells into darkness resulted in a rapid decline in acetylene-reducing activity, which became undetectable within $2 \mathrm{~h}$ (Fig. 5). This decline was similar to that observed in air. ATP and/or reductant were probably the essential factors supplied by light reactions. Addition of $2 \mathrm{mM}-\mathrm{NH}_{4} \mathrm{Cl}$ resulted in a slower decline of acetylene-reducing activity, perhaps because $\mathrm{NH}_{4}^{+}$may have acted by repressing nitrogenase synthesis rather than inhibiting its activity. $\mathrm{NO}_{3}^{-}$did not affect nitrogenase activity during the initial $2 \mathrm{~h}$ of incubation, but a slow decline in activity was seen thereafter. The difference in the effects of $\mathrm{NO}_{3}^{-}$and $\mathrm{NH}_{4}^{+}$ may be due to slower rates of nitrate uptake and/or metabolism in $\mathbf{N}_{2}$-fixing cultures (see below).

Table 1. $\mathrm{NO}_{3}^{-}$uptake and NR activities in P. boryanum, Gloeothece 6909 and $O$. limosa grown on $\mathrm{N}_{2}, \mathrm{NO}_{3}^{-}$or $\mathrm{NH}_{4}^{+}$

$\mathrm{NO}_{3}^{-}$uptake activities are expressed as $\mathrm{nmol} \mathrm{NO}_{3}^{-}$taken up $\min ^{-1}$ (mg protein)-1 and $\mathrm{NR}$ activities as nmol $\mathrm{NO}_{2}^{-}$formed $\min ^{-1}$ (mg protein) ${ }^{-1}$. NO ${ }_{3}^{-}$-medium represents BG-11 in the case of Gloeothece 6909 and $P$. boryanum, and $\mathrm{ASN}_{3}$ in the case of $O$. limosa. $\mathrm{N}_{2}$-medium represents the respective nitrogen-free medium (BG-1 $1_{0}$ or $\mathrm{NO}_{3}^{-}$-free $\mathrm{ASN}_{3}$ ). $\mathrm{NH}_{4}^{+}$-medium represents $\mathrm{N}_{2}$-media supplemented with $\mathrm{NH}_{4} \mathrm{Cl}$ (final concentration $2 \mathrm{mM}$ ) and buffered with $10 \mathrm{mM}-\mathrm{HEPES} / \mathrm{NaOH}(\mathrm{pH} 7.5)$. The values presented are means $\pm \mathrm{SE}$ of three measurements from a single experiment done in triplicate. ND, Not detectable.

\begin{tabular}{|c|c|c|c|c|c|c|}
\hline \multirow{2}{*}{$\begin{array}{l}\text { Growth } \\
\text { medium }\end{array}$} & \multicolumn{3}{|c|}{ Nitrate uptake } & \multicolumn{3}{|c|}{ Nitrate reductase } \\
\hline & Plectonema & Gloeothece & Oscillatoria & Plectonema & Gloeothece & Oscillatoria \\
\hline $\begin{array}{l}\mathrm{N}_{2} \text {-medium } \\
\mathrm{NO}_{3} \text {-medium }\end{array}$ & $\begin{array}{l}0.6 \pm 0.1 \\
7.5 \pm 0.3\end{array}$ & $\begin{array}{l}0.2 \pm 0.05 \\
4.9 \pm 0.25\end{array}$ & $\begin{array}{l}0.2 \pm 0.04 \\
6.0 \pm 0.30\end{array}$ & $\begin{array}{l}0.5 \pm 0.1 \\
7.8 \pm 0.4\end{array}$ & $\begin{array}{l}0 \cdot 2 \pm 0 \cdot 04 \\
4 \cdot 3 \pm 0 \cdot 10\end{array}$ & $\begin{array}{l}0.3 \pm 0.1 \\
4 \cdot 7 \pm 0.2\end{array}$ \\
\hline $\mathrm{NH}_{4}^{+}$-medium & ND & ND & ND & ND & ND & ND \\
\hline
\end{tabular}




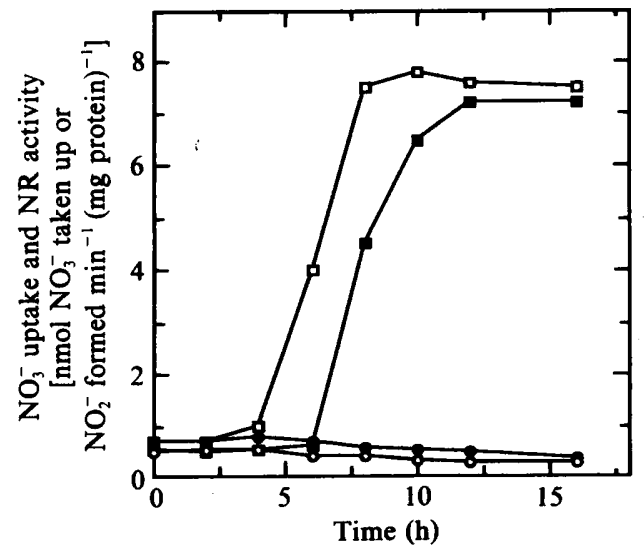

Fig. 6. Induction of $\mathrm{NO}_{3}^{-}$uptake $(\square, \bullet)$ and $\mathrm{NR}_{(\mathrm{O}}(\mathrm{O}, \mathrm{a})$ activities on transfer of $\mathrm{N}_{2}$-fixing $P$. boryanum cells to $\mathrm{NO}_{3}^{-}$-medium (BG-11 $1_{0}$ ) without $(\square, \square)$ or with $(O, \bullet)$ chloramphenicol $\left(100 \mu \mathrm{g} \mathrm{ml}^{-1}\right)$. Nitrogenase was derepressed as in Fig. 2(b). After the appearance of the nitrogenase peak, the cells were harvested by centrifugation and resuspended in $\mathrm{NO}_{3}^{-}$-medium (zero time), then maintained under aerobic growth conditions. At time intervals samples were withdrawn and $\mathrm{NO}_{3}^{-}$uptake rate and $\mathrm{NR}$ activities measured.

\section{$\mathrm{NO}_{\overline{3}}^{-}$uptake and $\mathrm{NR}$ activities}

$\mathrm{NO}_{3}^{-}$-grown cultures of $P$. boryanum showed $\mathrm{NO}_{3}^{-}$uptake and NR activities (Table 1) similar to those reported earlier (Ida \& Mikami, 1983). In contrast, the $\mathrm{NO}_{3}^{-}$ uptake and $\mathrm{NR}$ activities of $\mathrm{N}_{2}$-fixing cultures were only $10 \%$ of those in $\mathrm{NO}_{3}^{-}$-grown cells (activity measured after appearance of peak nitrogenase activity). These activities did not change during the period of nitrogenase decline that also corresponded to net $\mathrm{O}_{2}$ evolution and growth (data not shown). $\mathrm{NH}_{4}^{+}$-grown cells had no detectable levels of $\mathrm{NO}_{3}^{-}$uptake or NR. Essentially similar results were found in the case of the nonheterocystous cyanobacteria Gloeothece 6909 and $O$. limosa, which fix $\mathrm{N}_{2}$ aerobically (Table 1). When $\mathrm{N}_{2^{-}}$ fixing cells of $P$. boryanum were transferred to $\mathrm{NO}_{3}^{-}$medium, $\mathrm{NO}_{3}^{-}$uptake and $\mathrm{NR}$ activities increased, reaching a maximum within 10-12 h (Fig. 6). The increase was sensitive to chloramphenicol. These results imply that the $\mathrm{NO}_{3}^{-}$uptake and $\mathrm{NR}$ systems in $P$. boryanum are substrate-inducible and $\mathrm{NH}_{4}^{+}$-repressible.

\section{Nitrogenase localization}

Immunogold labelling of nitrogenase $\mathrm{Fe}$-protein in $\mathrm{NO}_{3}^{-}$grown cells (Fig. $7 a$ ) and $\mathrm{NH}_{4}$-grown cells (data not shown) showed label intensity similar to background (4-6 gold particles per $\mu \mathrm{m}^{2}$ cell area). $\mathrm{N}_{2}$-fixing
$P$. boryanum cells showed nitrogenase antigen uniformly distributed throughout the cell without preferential association with any cellular structure (Fig. 8a). All the cells in all the filaments examined had a similar pattern and intensity of labelling. Cells undergoing division also had nitrogenase label. The density of label was $95 \pm 12$ gold particles per $\mu \mathrm{m}^{2}$ cell area. These results confirm the lack of nitrogenase in $\mathrm{NO}_{3}^{-}$- and $\mathrm{NH}_{4}^{+}$-grown cells and imply no spatial separation or subcellular compartmentalization of nitrogenase in $P$. boryanum. Similar results have been reported in $P$. boryanum 581 using antibodies against nitrogenase Mo-Fe protein (Smoker et al., 1989).

\section{GS activity and cellular localization of GS antigen}

Potential changes in GS activity and protein concentration during derepression of nitrogenase were examined in $\mathrm{NO}_{3}^{-}$-grown and in $\mathrm{N}_{2}$-fixing $P$. boryanum cells. GS biosynthetic activity in the two cultures was $45 \pm 2.8$ and $56 \pm 3.1 \mathrm{nmol}$ product formed $\mathrm{min}^{-1}(\mathrm{mg}$ protein) ${ }^{-1}$, respectively. Immunolabelling experiments showed that the GS antigen was distributed throughout the cell both in $\mathrm{NO}_{3}^{-}$-grown and in $\mathrm{N}_{2}$-fixing cells (Figs $7 b, 8 b$ ). The relative densities of the gold label were $22 \pm 2.5$ and $27 \pm 2.6$ gold particles per $\mu \mathrm{m}^{2}$ cell area, respectively. Thus, a $20 \%$ increase in GS activity and protein label occurred on nitrogenase derepression. This is in contrast to the report of Nagatani \& Haselkorn (1978), who found no increase in GS activity during nitrogenase derepression under an argon atmosphere. The differences may have arisen due to different conditions used for nitrogenase derepression, including the fact that we used $\mathrm{N}_{2} / \mathrm{CO}_{2}(95: 5, \mathrm{v} / \mathrm{v})$ for nitrogenase derepression.

\section{Rubisco localization}

Rubisco was localized in $\mathrm{NO}_{3}^{-}$-grown and in $\mathrm{N}_{2}$-fixing cells of $P$. boryanum (Figs $7 c, 8 c$ ). In the latter case, the cells were processed for immunolabelling at the beginning of the appearance of nitrogenase, when the nitrogen stress, and therefore the difference in Rubisco, is likely to be highest. Rubisco was present in both $\mathrm{NO}_{3}^{-}$-grown and $\mathbf{N}_{2}$-fixing cells. In both cases, an intense labelling was found in carboxysomes and a lower intensity in the cytoplasm. The overall level of Rubisco in $\mathrm{N}_{2}$-fixing cells was $20 \%$ lower than that in $\mathrm{NO}_{3}^{-}$-grown cells $(43 \pm 3 \cdot 4$ and $54 \pm 4$ gold particles per cell, respectively). Smoker et al. (1990) noted a much higher (over $50 \%$ ) reduction

Fig. 7. Immunogold localization of nitrogenase (a), GS (b), Rubisco (c) and PE (d) in $\mathrm{NO}_{3}^{-}$-grown cells of $P$. boryanum. Rabbit anti- $R$. rubrum nitrogenase Fe-protein (a), anti-Anabaena $7120 \mathrm{GS}(b)$, anti-S. alba Rubisco (c) and anti-P. persicinum PE (d) were used as primary antibodies at a dilution of $1: 100$. Goat anti-rabbit IgG conjugated to $5 \mathrm{~nm}(a, c, d)$ or $10 \mathrm{~nm}(b)$ colloidal gold was used as secondary antibody at a dilution of $1: 20$. $\mathrm{Cb}$, carboxysome. Bar, $1 \mu \mathrm{m}$ (all parts of the figure are at the same magnification). 

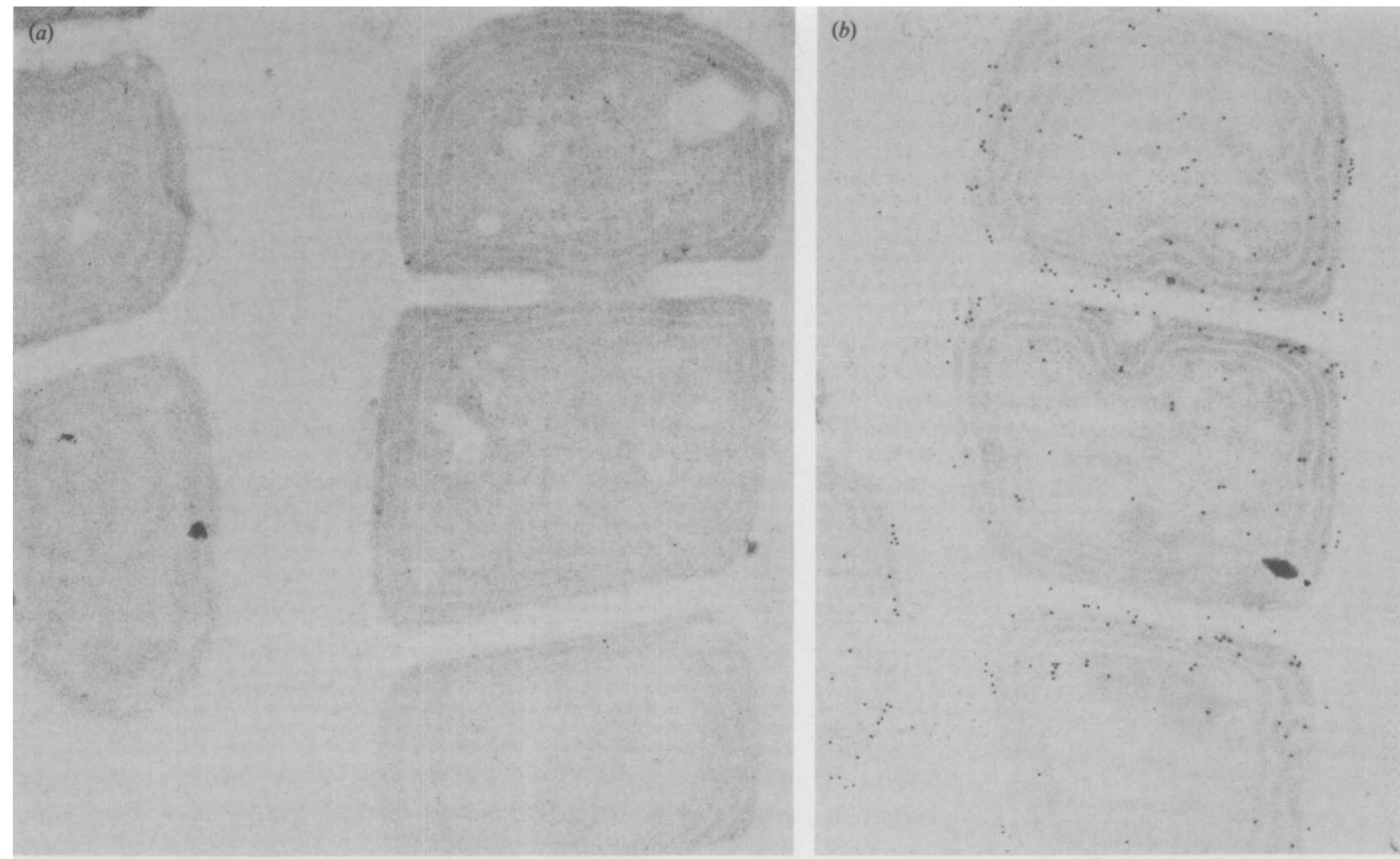

(c)

(d)

$\mathrm{Cb}$ 

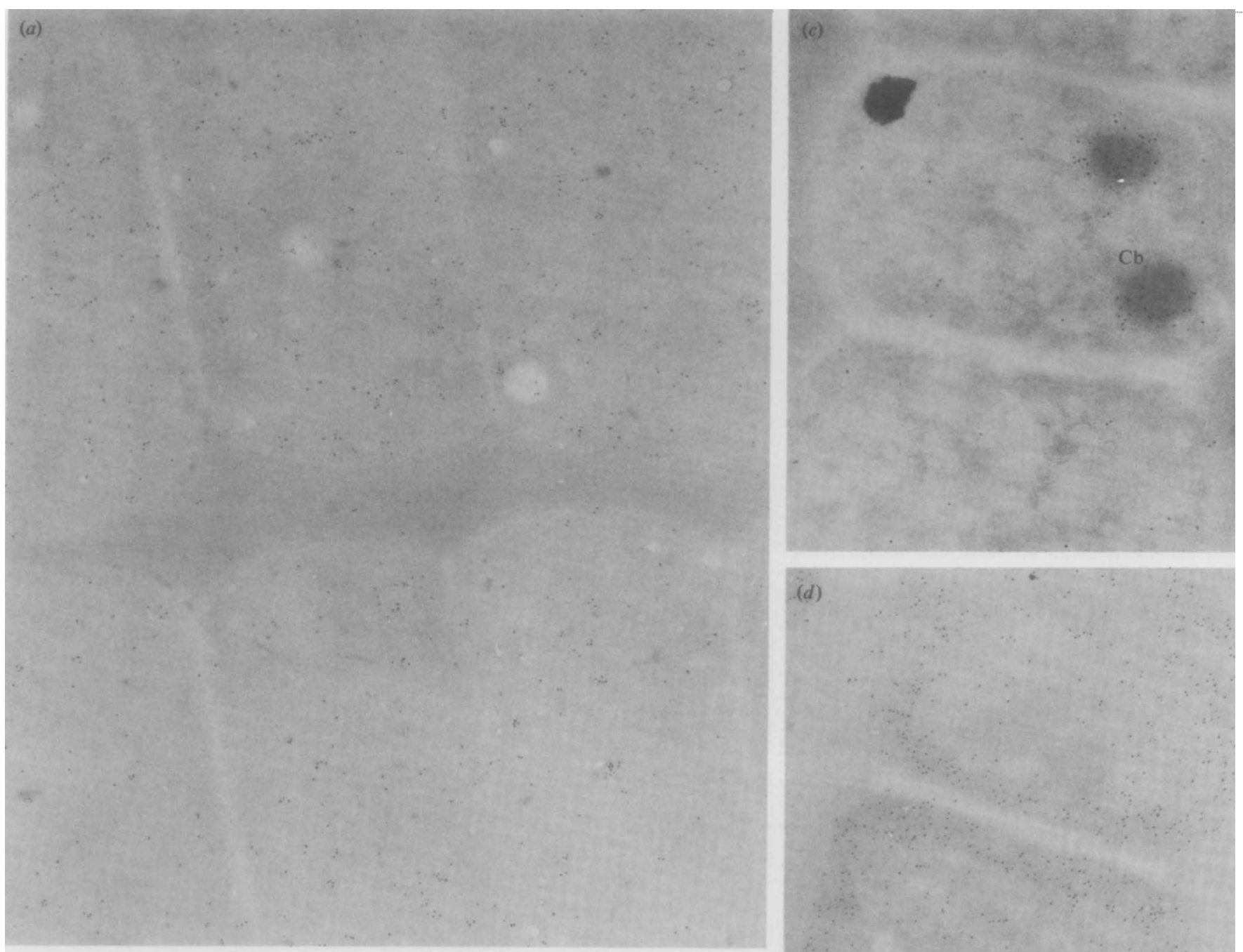

(b)

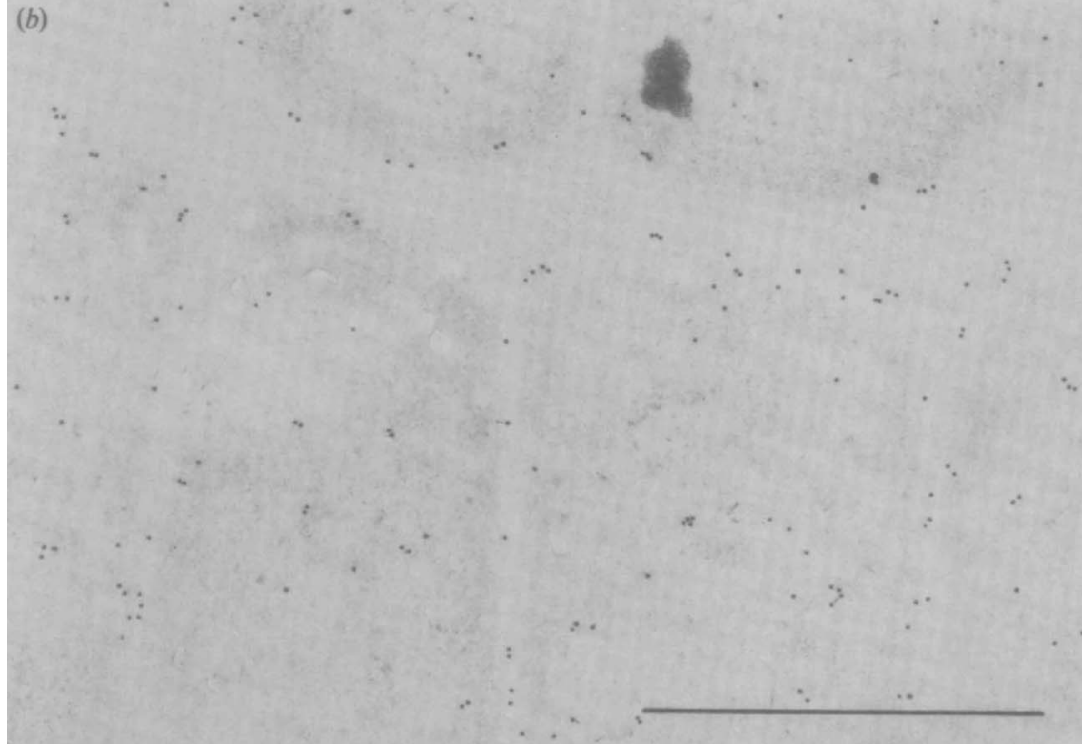


in Rubisco levels on nitrogenase derepression in $P$. boryanum 581. However, the cells had been stressed for nitrogen for $40 \mathrm{~h}$ in an argon atmosphere lacking $\mathrm{N}_{2}$. These results show that unlike the situation in heterocysts, derepression of nitrogenase in $P$. boryanum does not lead to a total loss of Rubisco.

\section{Localization of $P E$}

During nitrogenase derepression in $P$. boryanum, a transient decrease in phycocyanin has been noted (Stewart \& Lex, 1970; Weare \& Benemann, 1974). To see if $\mathrm{PE}$ concentrations also change during nitrogenase derepression, immunogold labelling of $\mathrm{PE}$ was examined in $\mathrm{NO}_{3}^{-}$-grown and in $\mathrm{N}_{2}$-fixing cells. In the latter case, cells for immunolabelling were taken at the beginning of the appearance of nitrogenase activity, when the differences are likely to be maximal. An intense PE labelling associated with thylakoid membranes was found both in $\mathrm{NO}_{3}^{-}$-grown and in $\mathrm{N}_{2}$-fixing cells (Figs $7 d, 8 d)$. In both cases, the amounts of PE were similar $(447 \pm 15$ and $435 \pm 18$ gold particles per cell, respectively), indicating little or no degradation of PE in $P$. boryanum under the conditions of nitrogenase derepression used here.

\section{Discussion}

Under a $\mathrm{N}_{2} / \mathrm{CO}_{2}$ atmosphere $P$. boryanum PCC 73110 synthesized nitrogenase and showed nitrogenase activity in the absence of combined nitrogen (Figs 2, 4). These activities are among the highest reported by other workers using this strain (Stewart \& Lex, 1970; Weare \& Benemann, 1974; Nagatani \& Haselkorn, 1978; Rogerson, 1980; Pearson \& Howsley, 1980; Giani \& Krumbein, 1986). Since the cultures used were nonsynchronous, development of nitrogenase in all the cells (including those undergoing cell division) and the uniform distribution throughout the cells (Fig. 8) argue against the possibility of nitrogenase being expressed during a particular phase of the cell cycle or being compartmentalized within the cell (Mitsui et al., 1986; Giani \& Krumbein, 1986). Similar patterns of labelling have been found in $O$. limosa (Stal \& Bergman, 1990), $P$. boryanum UTEX 581 (Smoker et al. 1989) and Gloeothece PCC 6909 (A. N. Rai \& B. Bergman, unpublished results).

$\mathrm{O}_{2}$ removal or nitrogen limitation alone did not lead to derepression of nitrogenase. This was indicated by the lack of nitrogenase derepression under aerobic con- ditions irrespective of the nitrogen status of the cell, and by the fact that even on $\mathrm{N}_{2} / \mathrm{CO}_{2}$ sparging nitrogenase derepression occurred only under nitrogen-limited conditions (Figs 2, 3, 7a). These results are consistent with, and provide evidence for, the suggestion that nitrogenase derepression in $P$. boryanum requires both $\mathrm{O}_{2}$ removal and nitrogen limitation (Nagatani \& Haselkorn, 1978). Absence of nitrogenase derepression in the presence of combined nitrogen is consistent with earlier observations in cyanobacteria including $\boldsymbol{P}$. boryanum (Stewart, 1980; Gallon, 1989; Stewart \& Lex, 1970). However, the fact that $\mathrm{O}_{2}$ removal or lowering of $\mathrm{O}_{2}$ tension was necessary for nitrogenase derepression, despite a temporal separation of net $\mathrm{O}_{2}$ evolution and nitrogenase activity, and that nitrogenase activity declined sharply on exposure to air or with the onset of net $\mathrm{O}_{2}$ evolution endogenously (Fig. 4), suggests that the $\mathrm{O}_{2}$-scavenging capacity in $P$. boryanum is much more limited than in other non-heterocystous cyanobacteria. Indeed, Weare \& Benemann (1974) found respiration to be of only limited significance in $\mathrm{O}_{2}$-protection in $P$. boryanum.

Our studies showing irreversible inactivation of nitrogenase by $\mathrm{O}_{2}$ in $P$. boryanum (Fig. 3) are consistent with the results of Weare \& Benemann (1974). Nitrogenase $\mathrm{Fe}$-protein has been shown to be modified to a higher molecular mass form by $\mathrm{O}_{2}$ in some heterocystous cyanobacteria, which results in reversible inactivation of the protein but renders it insensitive to $\mathrm{O}_{2}$ damage (Smith et al., 1987; Reich \& Böger, 1989; Ernst et al., 1990). A similar form has also been noted in $O$. limosa (Stal \& Bergman, 1990). The fact that such a modification was not found in $P$. boryanum (Fig. $3 b$ ) may explain why inactivation of nitrogenase in this strain was irreversible and resulted in degradation of the enzyme.

The temporal separation of $\mathrm{N}_{2}$ fixation and net $\mathrm{O}_{2}$ evolution noted here (Fig. 4) also confirms the findings of Weare \& Benemann (1974). In addition, the results show that $P$. boryanum can grow photoautotrophically with repeated cycles of $N_{2}$ fixation and growth. Since nitrogenase was found to be irreversibly inactivated and degraded on exposure to air, and regain of nitrogenase activity required fresh synthesis of nitrogenase (Figs 3, 5 ), it is possible that repeated phases of $\mathbf{N}_{2}$ fixation required fresh nitrogenase synthesis and that during the following microaerobic phase nitrogenase was degraded. Giani \& Krumbein (1986) have demonstrated $\mathrm{N}_{2}$ fixation and concomitant photoautotrophic growth in $P$. boryanum at lower light intensities with continuous $\mathrm{N}_{2} / \mathrm{CO}_{2}$ flushing. Thus, depending on the culture conditions, $P$. boryanum seems capable of photoauto-

Fig. 8. Immunogold localization of nitrogenase (a), GS $(b)$, Rubisco $(c)$ and PE $(d)$ in $\mathrm{N}_{2}$-fixing $P$. boryanum cells. Nitrogenase derepression was achieved as in Fig. 2(b). The cells used for immunolabelling were sampled either at the beginning $(c, d)$ or at the peak $(a, b)$ of nitrogenase activity. Other details as in Fig. 7 . 
trophic growth either with repeated phases of $\mathrm{N}_{2}$ fixation (when sparged with $\mathrm{N}_{2} / \mathrm{CO}_{2}$ periodically) or concomitantly with continuous $\mathrm{N}_{2}$ fixation (when sparged with $\mathrm{N}_{2} / \mathrm{CO}_{2}$ continuously to remove any net $\mathrm{O}_{2}$ evolved, keeping the culture microaerobic). Although the precise mechanism of temporal separation is not clear, it is possible that this is achieved by changes in rates of photosynthesis, with respiration balancing photosynthetic $\mathrm{O}_{2}$ evolution during $\mathrm{N}_{2}$ fixation while increased rates of photosynthesis result in net $\mathrm{O}_{2}$ evolution during the growth that follows. This may occur due to transient changes in phycobiliprotein levels. Although we found no significant changes in PE levels (Figs 7,8), phycocyanin levels are known to change and repeated degradation and synthesis of phycocyanin has been noted earlier (Stewart \& Lex, 1970; Weare \& Benemann, 1974; Giani \& Krumbein, 1986).

Mo may be a limiting factor in cyanobacterial cells (Bagchi et al., 1985). Nitrogenase and NR are both molybdoenzymes and require reduced ferredoxin as electron donor (Guerrero \& Lara, 1987). Indeed Nagatani \& Haselkorn (1978) have shown that in absence of Mo, the nitrogenase proteins synthesized are inactive. Occurrence of NR and nitrogenase in the same cell is likely to lead to competition for Mo and reduced ferredoxin. Heterocystous cyanobacteria avoid such competition by spatial separation of nitrogenase and NR (Kumar et al., 1985, Rai \& Bergman, 1986). Such spatial separation is not possible in non-heterocystous cyanobacteria since nitrogenase is present in all the cells. A temporal separation of NR and nitrogenase activity was not found in the non-heterocystous cyanobacteria tested (Table 1). However, the fact that nitrate uptake and NR were found to be $\mathrm{NO}_{3}^{-}$-inducible, with very low activities in $\mathrm{N}_{2}$-fixing cultures (Fig. 6; Table 1) means that these cyanobacteria are able to effectively minimize competition between NR and nitrogenase under diazotrophic growth conditions. It is noteworthy that $\mathrm{N}_{2}$-fixing $P$. boryanum cells retain the capacity to develop nitrate uptake and NR (Fig. 6), unlike heterocysts, where these systems are lost (Rai \& Bergman, 1986).

As in heterocystous cyanobacteria, the GS-GOGAT pathway has been shown to be the route of primary $\mathrm{NH}_{4}^{+}$ assimilation in $P$. boryanum (Meeks et al. 1978). An increase in GS activity and protein level has been noted when vegetative cells differentiate into heterocysts (see Wolk, 1982; Bergman et al., 1985). This has been shown to be linked to nitrogenase expression and to be necessary for assimilation of $\mathrm{N}_{2}$-derived $\mathrm{NH}_{4}^{+}$ (Renström-Kellner et al., 1990). Our results showing an increase of GS with derepression of nitrogenase (Figs 7, 8 ) are consistent with the above view. These findings also explain why $\mathrm{NO}_{3}^{-}$is less inhibitory and acts more slowly than $\mathrm{NH}_{4}^{+}$. As mentioned above, $\mathrm{NO}_{3}^{-}$uptake and $\mathrm{NR}$ levels are very low in $\mathrm{N}_{2}$-fixing cultures and availability of $\mathrm{NO}_{3}^{-}$requires 3-4 $\mathrm{h}$ for induction of $\mathrm{NO}_{3}^{-}$uptake and $\mathrm{NR}$ activity (Table 1, Fig. 6), while $\mathrm{NH}_{4}^{+}$assimilation remains active throughout. These effects resemble the effects of $\mathrm{NO}_{3}^{-}$and $\mathrm{NH}_{4}^{+}$on nitrogenase activity and protein in heterocysts (Renström-Kellner et al., 1990). Thus, during $\mathrm{N}_{2}$ fixation $P$. boryanum cells functionally resemble heterocysts. However, unlike heterocysts, $\mathrm{N}_{2}-$ fixing $P$. boryanum cells retain PE and Rubisco (Figs 7, 8 ), they retain the capacity to develop $\mathrm{NO}_{3}^{-}$uptake and NR activity on nitrate availability (Fig. 6), and their PC levels change only transiently (Stewart \& Lex, 1970; Weare \& Benemann, 1974; Giani \& Krumbein, 1986).

We thank SAREC (Sweden) and CSIR (India) for financial support, Lucas Stal (University of Amsterdam) for providing the Oscillatoria limosa strain, and North-Eastern Hill University (Shillong, India) for grant of a Sabbatical Leave to A.N.R.

\section{References}

Bagchi, S. N., RAI, A. N. \& SiNGH, H. N. (1985). Regulation of nitrate reductase in cyanobacteria: represssion-derepression control of nitrate reductase apoprotein in the cyanobacterium Nostoc muscorum. Biochimica et Biophysica Acta 383, 370-373.

Bergman, B. \& RaI, A. N. (1989). The Nostoc-Nephroma symbiosis: localization, distribution pattern and levels of key proteins involved in nitrogen and carbon metabolism of the cyanobiont. Physiologia Plantarum 77, 216-224.

Bergman, B., Lindblad, P., Pettersson, A., Renström, E. \& Tiberg, E. (1985). Immuno-gold localization of glutamine synthetase in a nitrogen-fixing cyanobacterium (Anabaena cylindrica). Planta 166, 329-334.

Bergman, B., Lindblad, P. \& Rai, A. N. (1986). Nitrogenase in freeliving and symbiotic cyanobacteria: immunoelectron microscopic localization. FEMS Microbiology Letters 35, 75-78.

BRADFORD, M. M. (1976). A rapid and sensitive method for the quantitation of microgram quantities of protein utilizing the principle of protein-dye binding. Analytical Biochemistry 72, $248-254$.

Braun-Howland, E. B., Lindblad, P., Nierzwicki-Bauer, S. A. \& BergmaN, B. (1988). Dinitrogenase reductase (Fe-protein) of nitrogenase in the cyanobacterial symbionts of three Azolla species: localization and sequence of appearance during heterocyst differentiation. Planta 176, 319-333.

Calero, F., UllRich, W. R. \& APARICIO, P. J. (1980). Regulation by monochromatic light of nitrate uptake in Chlorella fusca. In The Blue Light Syndrome, pp. 411-421. Edited by H. Senger, Berlin: SpringerVerlag.

ERnst, A., ReICH, S. \& BöGer, P. (1990). Modification of dinitrogenase reductase in the cyanobacterium Anabaena variabilis due to $C$ starvation and ammonia. Journal of Bacteriology 172, 748-755.

GaLlON, J. R. (1989). The physiology and biochemistry of $\mathrm{N}_{2}$-fixation by non-heterocystous cyanobacteria. Phykos 28, 18-46.

GiaNi, D. \& KRUMBeIN, W. E. (1986). Growth characteristics of nonheterocystous cyanobacterium Plectonema boryanum with $\mathrm{N}_{2}$ as nitrogen source. Archives of Microbiology 145, 259-265.

GuerRero, M. G. \& LARA, C. (1987). Assimilation of inorganic nitrogen. In The Cyanobacteria, pp. 163-186. Edited by P. Fay \& C. Van Baalen. Amsterdam: Elsevier.

IDA, S. \& MIKAMI, B. (1983). Purification and characterization of assimilatory nitrate reductase from the cyanobacterium Plectonema boryanum. Plant and Cell Physiology 24, 649-658.

Kumar, A. P., Rai, A. N. \& Singh, H. N. (1985). Nitrate reductase activity in isolated heterocysts of the cyanobacterium Nostoc muscorum. FEBS Letters 179, 125-128. 
MACKINNEY, G. (1941). Absorption of light by chlorophyll solutions. Journal of Biological Chemistry 140, 315-322.

manzano, C., Candau, P., Gomez-Moreno, C., Relimpio, A. M. \& LOSADA, M. (1976). Ferredoxin dependent photosynthetic reduction of nitrate and nitrite by particles of Anacystis nidulans. Molecular and Cellular Biochemistry 10, 161-169.

Mitsui, A., Kumazawa, S., Takahashi, A., Ikemoto, H., Cao, S. \& ARAI, T. (1986). Strategy by which nitrogen-fixing unicellular cyanobacteria grow photoautotrophically. Nature, London 323, 720-722.

Meeks, J. C., Wolk, C. P., Lockau, W., Schilling, N., Shaffer, P. W. \& CHIEN, W.-S. (1978). Pathways of assimilation of $\left[{ }^{13} \mathrm{~N}\right] \mathrm{N}_{2}$ and ${ }^{13} \mathrm{NH}_{4}$ by cyanobacteria with and without heterocysts. Journal of Bacteriology 134, 125-130.

Nagatani, H. \& Haselkorn, R. (1978). Molybdenum independence of nitrogenase component synthesis in the non-heterocystous cyanobacterium Plectonema. Journal of Bacteriology 134, 597-605.

Pearson, H. W. \& Howsley, R. (1980). Concomitant photoautotrophic growth and nitrogenase activity by cyanobacterium Plectonema boryanum in continuous culture. Nature, London 288 , 263-265.

RAI, A. N. \& Bergman, B. (1986). Modification of $\mathrm{NO}_{3}^{-}$metabolism in heterocysts of the $\mathrm{N}_{2}$-fixing cyanobacterium Anabaena 7120 (ATCC 27893). FEMS Microbiology Letters 36, 133-137.

REICH, S. \& BöGER, P. (1989). Regulation of nitrogenase activity in Anabaena variabilis by modification of the Fe-protein. FEMS Microbiology Letters 58, 81-86.

Renström-Kellner, E., RAI, A. N. \& Bergman, B. (1990). Correlation between nitrogenase and glutamine synthetase expression in the cyanobacterium Anabaena cylindrica. Physiologia Plantarum 80, 12-19.

Rippka, R., Deruelles, J., Waterbury, J. B., Herdman, M. \& StANIER, R. Y. (1979). Generic assignments, strain histories and properties of pure culturess of cyanobacteria. Journal of General Microbiology 111, 1-61.

Rogerson, A. C. (1980). Nitrogen-fixing growth by non-heterocystous cyanobacterium Plectonema boryanum. Nature, London 284, 563-564.
Sampaio, M. J. A. M., Rowell, P. \& Stewart, W. D. P. (1979). Purification and some properties of glutamine synthetase from the nitrogen-fixing cyanobacteria Anabaena cylindrica and Nostoc sp. Journal of General Microbiology 111, 181-191.

Smith, R. L., Van BaAlen, C. \& Tabita, F. R. (1987). Alteration of the $\mathrm{Fe}$-protein of nitrogenase by oxygen in the cyanobacterium Anabaena sp. strain CA. Journal of Bacteriology 169, 2537-2542.

SMOKer, J. A., OWEN, H. A., LehNen, L. P. \& BarNum, S. R. (1989). Ultrastructure of the nitrogen-fixing, filamentous, nonheterocystous cyanobacterium, Plectonema boryanum. Protoplasma 152, 130-135.

SMOKER, J. A., OWEN, H. A. \& BARNUM, S. R. (1990). Immunogold localization of ribulose-1,5-bisphosphate carboxylase/oxygenase in the nitrogen-fixing cyanobacterium, Plectonema boryanum. Protoplasma 156, 113-116.

SNELL, F. D. \& SNELl, C. T. (1949). Colorimetric Methods of Analysis, vol. 3, pp. 804-805. New York: D. van Nostrand Co.

STAL, L. J. \& BERGMAN, B. (1990). Immunological characterization of nitrogenase in the filamentous non-heterocystous cyanobacterium Oscillatoria limosa. Planta 182, 287-291.

StEWART, W. D. P. (1980). Some aspects of structure and function in $\mathrm{N}_{2}$-fixing cyanobacteria. Annual Review of Microbiology 34, 497536.

STEWART, W. D. P. \& LEX, M. (1970). Nitrogenase activity in the bluegreen alga Plectonema boryanum strain 594. Archiv für Mikrobiologie 73, 250-260

Stewart, W. D. P., Fitzgerald, G. P. \& BurRis, R. H. (1967). In situ studies on $\mathrm{N}_{2}$-fixation using the acetylene reduction technique. Proceedings of the National Academy of Sciences of the United States of America 58, 2071-2078.

Weare, N. M. \& BenemanN, J. R. (1974). Nitrogenase activity and photosynthesis in Plectonema boryanum. Journal of Bacteriology 119 , 258-265.

WEISSHAAR, H. \& BöGER, P. (1983). Nitrogenase activity of the nonheterocystous cyanobacterium Phormidium faveolarum. Archives of Microbiology 136, 270-274.

WoLK, C. P. (1982). Heterocysts. In The Biology of Cyanobacteria, pp. 359-386. Edited by N. G. Carr \& B. A. Whitton. Oxford: Blackwell. 